\title{
Preparing A Land Cover Map with Emphasis on Green Space (Grass, Tree, Agriculture): by using Image Texture Filters in Panchromatic Band, Iran
}

\author{
Kaveh Ostad-Ali-Askari ${ }^{1 *}$, Zahra Qasemy ${ }^{1}$, Saeid Eslamian², Mojtaba Pirnazar ${ }^{2}$, Aria Namadi ${ }^{3}$, \\ Vijay P. Singh ${ }^{4}$, Nicolas R. Dalezios ${ }^{5}$, Mohammed Matouq ${ }^{6}$, Mohsen Ghane $^{7}$, Sadegh Khani ${ }^{1}$

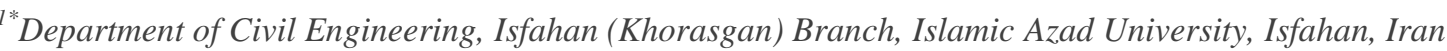 \\ ${ }^{I}$ Department of Remote Sensing, Yazd Branch, Islamic Azad University, Iran \\ ${ }^{2}$ Department of Water Engineering, Isfahan University of Technology, Isfahan, Iran \\ ${ }^{2}$ Department of Remote Sensing, Tabriz University, Tabriz, Iran \\ ${ }^{3}$ Department of Civil Engineering, Najafabad Branch, Islamic Azad University, Najafabad, Iran \\ ${ }^{4}$ Department of Biological and Agricultural Engineering \&Zachry Department of Civil Engineering, Texas A \\ and M University, 321 Scoates Hall, 2117 TAMU, College Station, Texas 77843-2117, U.S.A. \\ ${ }^{5}$ Laboratory of Hydrology, Department of Civil Engineering, University of Thessaly, Volos, Greece \& \\ Department of Natural Resources Development and Agricultural Engineering, Agricultural University of \\ Athens, Athens, Greece. \\ ${ }^{6}$ Al-Balqa Applied University, Chemical Engineering Department, President of Jordan Japan Academic Society, \\ JJAS,P.O. Box 4486, Amman 11131- Jordan. \\ ${ }^{7}$ Department of Civil Engineering, South Tehran Branch, Islamic Azad University, Tehran, Iran
}

*Corresponding Author: Dr. Kaveh Ostad-Ali-Askari, Department of Civil Engineering, Isfahan (Khorasgan) Branch, Islamic Azad University, Isfahan, Iran.Emails: Koa.askari@khuisf.ac.ir, Kaveh.oaa2000@gmail.com

\begin{abstract}
Satellite data are currently considered as one of the most important sources in producing usemap and land coverage. Several digital classification methods have been proposed for such maps which are now being used. Accordingly, evaluating and comparing different methods for determining the appropriate and principled method is of utmost importance in different situations in the country. High-resolution images available for sensors, such as Ikonos and QuickBird are more efficient than digital operating systems that provide opportunities for details of large-scale land cover maps. In this article panchromatic band of QuickBird images is used in Northeast of Isfahan in 2006. Image texture is used for processing panchromatic band. To extract the texture of six soil cover (explained in this research), the author used the filters in the software Envi. 4. 8. About $80 \%$ resolution for greenspace cover implies the acceptability of this method.
\end{abstract}

Keywords: land cover, high resolution, texture, Greenspace image, Isfahan

\section{INTRODUCTION}

In order to reach the land cover graph on a global and regional scale, accessing updated field data are usually difficult and limited, since such data are collected from accessible places at a generally small level and at different intervals which vary from one another in terms of type and credit. Using conventional and traditional methods of harvesting and measuring earth requires a lot of time and money, and still, is impossible to perform in some difficult-to-pass areas.

The use of satellite imagery is of particular importance due to special features such as wide vision, low cost, use of different parts of the electromagnetic spectrum to record the properties of phenomena, aperiod of a short return, the possibility of automatic analysis, faster investigation and the possibility of monitoring the region. Remote sensing data with features such as frequent imaging at low intervals, vastness of land cover surface detected by sensors, proper spectral and spatial separation; provide a suitable tool for the landcover graph. Today's advances provide significant opportunities and achievements for observing and managing the rapid growth of cities in remote sensing and geographic information systems. One of the characteristics of remote sensing sensors is as patial resolution. Each sensor with different spatial resolution is used in a different application. In recent years images from high-resolution sensors have been considered as one of the newly used achievements in remote- 
sensing. The spatial resolution of these sensors is often between 0.4 and 6 meters. Due to satellite imagery's high spatial resolution, spatial changes are increased so as a result, the variance of each class rises; this spreads probability density functions of classes and results in a high degree of overlap between the two which itself raises the classification error. To reduce error in such imagesone needs to use spatial information (textural)as well as spectral information. Managers and urban planners need a tool to provide them the correct, fast and updated information. There are the most common classification methods used in remote sensing as non-regulatory classification like Isodata and regularly methods as maximum likelihood methods in which each spectral class is described by a multivariate normal distribution. (Salami, 2009, 258-266) Matin-Far, H et al. (2007) examined determining the type of land use and land coverage by Landsat7 ETM+ and by using object-oriented methods in Kashan's dry areas. The accuracy of the object-oriented method is 95, and, therefore, it can be concluded that object-oriented method is suitable for the study of dry areas. (Saroasta et al. 2012) used some remote sensing techniques to check land cover variations such as SVM, Artificial Neural Networks, and the most probable classification. The images used in this research study are of Landsat's. Results showed that SVM technique is more suitable than other two techniques. Alimohammadi et al. (2009) compared pixel-based methods, base object and decision tree in preparing forest types maps by using forest data and remote sensing data.The overall accuracy of 54\% and Kappa coefficient of 39\% is achieved for the based-pixel method. In theobject-oriented method, the overall accuracy is 63 and Kappa coefficient is $54 \%$. By using auxiliary data such as height in decision tree method the overall accuracy and the Kappa coefficient reach 76 and 0.7 respectively.Results show that the object-oriented method is more efficient than pixel-based method and decision tree method (which uses auxiliary data) for separating tree species in mixed forests. Lotfi, Sad et al. (2010) examined applications of Spot satellite imagery for preparing a land use map of Marand County with anobject-oriented approach. To classify land cover and land use in Terminus Lagoon in the southeastern of Mexico, MAS (2003)utilized multilayer perceptron (MLP) neural network algorithm. Neural network inputs for band 2.3, 4, 5, 7 were ETM sensor of Landsat satellite and six class of land cover were prepared as output. The accuracy of the classification was reported: 82\%. (MAS.2003:3498-3500). Using Landsat images, Membini et al. (2013) compared the maximum likelihood method to the fuzzy method in thepreparation of land cover/ land use map in thesouth of Khuzestan. Results show that the fuzzy method with Kappa coefficient of $99 \%$ is more accurate than maximum likelihood method with Kappa coefficient of 98\%. Using fuzzy Artmap method and multilayer perceptron neural network, Zaeri, Amirani, Safianian examined Isfahan for preparing theland cover map. Results on the image LISS-III showed that multilayered perceptron neural network method with anaccuracy of 93.3 is more precise than thefuzzy method with anaccuracy of $88 \%$. Kate et al. (2012) in a study based on image texture identified underprivileged urban areas in Hyderabad, India. Closely-packed housing is the key feature of theslum. The method used for preparing maps of slum areas in populated cities is reliable and could be used for examining multidimensional data in developing cities.

\section{Methods AND MATERIALS}

Isfahan is located $435 \mathrm{~km}$ from south of Tehran. The City of Isfahan has a longitude of 51 degrees, 39 minutes and 40 seconds east and latitude of 32 degrees, 38 minutes and 30 seconds north. Its urban area is divided into 14 regions. Outside of the urban area, Khomeini Shahr and Najafabad are in the west, Mount Sofeh and Sepahan Shahr in the south, Shahin Shahr in the north and Segzi plain is located in the east of the city. According to Figure (1), the area under study is north of the city.

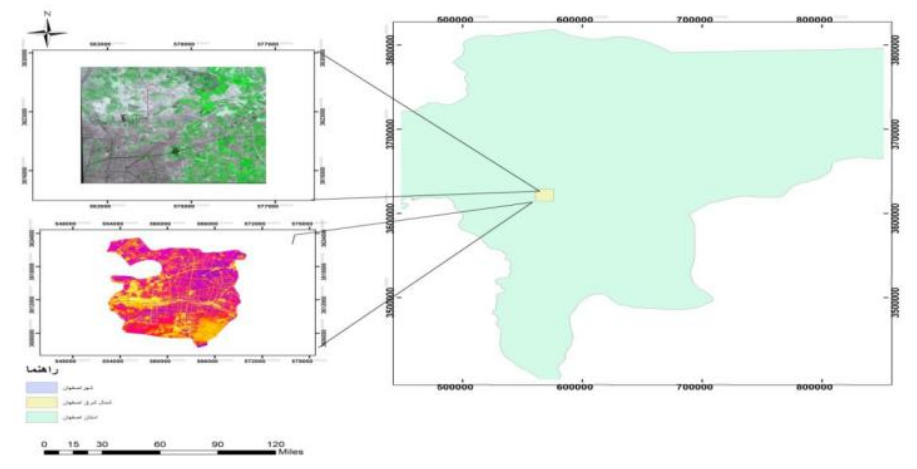

Fig1. Geographical location of the area 


\section{Classification Accuracy in Quick Bird Color Image}

To compare colored band to panchromatic band, at first, Quick Bird color image of northeast of Isfahan is classified into six classes of land cover using maximum likelihood classification. As seen in Fig (2), the overall accuracy is $86.27 \%$ and the Kappa coefficient is $81 \%$.

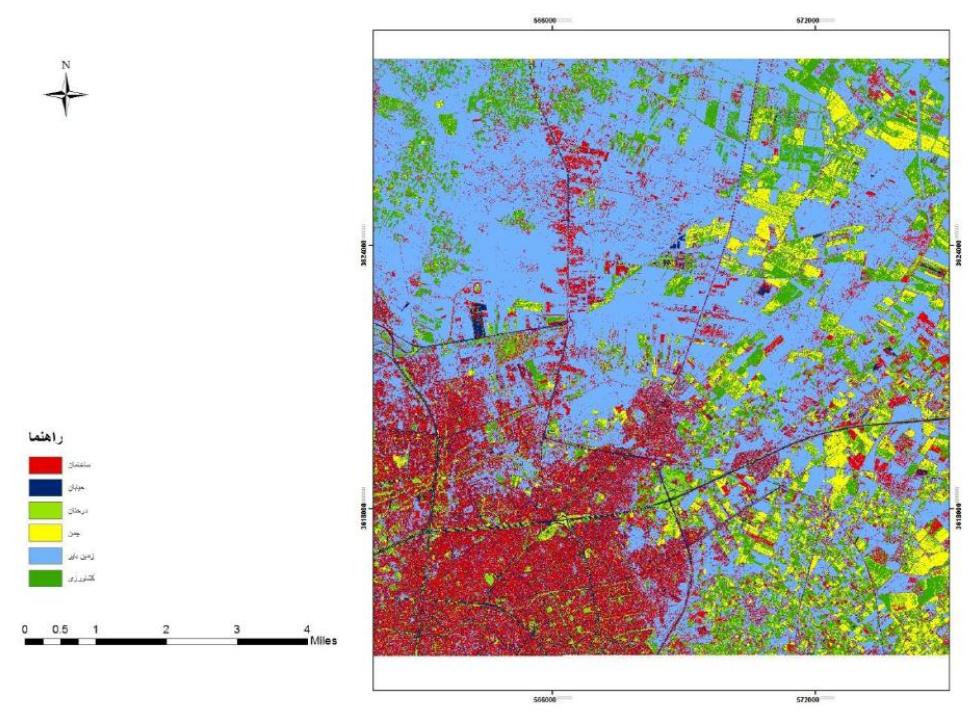

Fig2. Maximum likelihood classification in Quick Bird color image of Isfahan Panchromatic band classification

In this panchromatic band research study, in order to obtain higher precision, Quick Bird image is used rather than acolor image. To detect texture in images, the texture filter tool in the software ENVI4.8 is used. After performing the pre-processing step on all images, they are ready to be processed. In the first step, texture filtering is applied.

\section{Data Range Filter}

As it is reflected in Fig (3), the filter has a dark color in the green grass band. Barren land also has a dark color, but due to the fact that the barren land does not have a smooth surface, the pixels are not uniformly distributed in terms of darkness as opposed to theshadow of the building which has a completely dark color which can almost be distinguished from all other phenomena in this filter. What separates the phenomena in this filter is the boundary of the phenomena.

Since the color of all phenomena except shadows and cars are dark in the filter, the boundaries of phenomena are sharp and bright. Roads inside the city are also dark gray and in terms of color, they are similar to grass. The greenspace of the buildings in this filter does not have the same texture and the texture is irregular. The degree of greynessof the phenomena is constantly changing in greenspace and buildings, it could be said that there is no regular continuity. Buildings have sharp and white edges. Shadow of the trees darkened the road, therefore, the existence of trees can be proven.

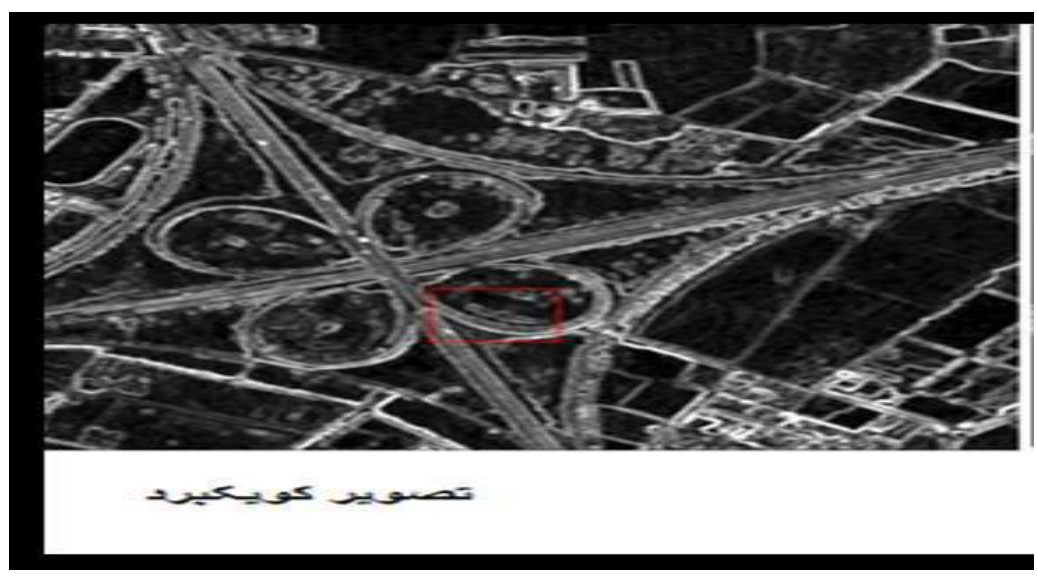

Fig3. Data Range Filter 
Preparing A Land Cover Map with Emphasis on Green Space (Grass, Tree, Agriculture): by using Image Texture Filters in Panchromatic Band, Iran

\section{Mean Filter}

In this filter, phenomena retain their shape on the image. Fig (4) shows that based on the shape, our visual interpretation, experiences and mental image are distinguishable from the phenomena.

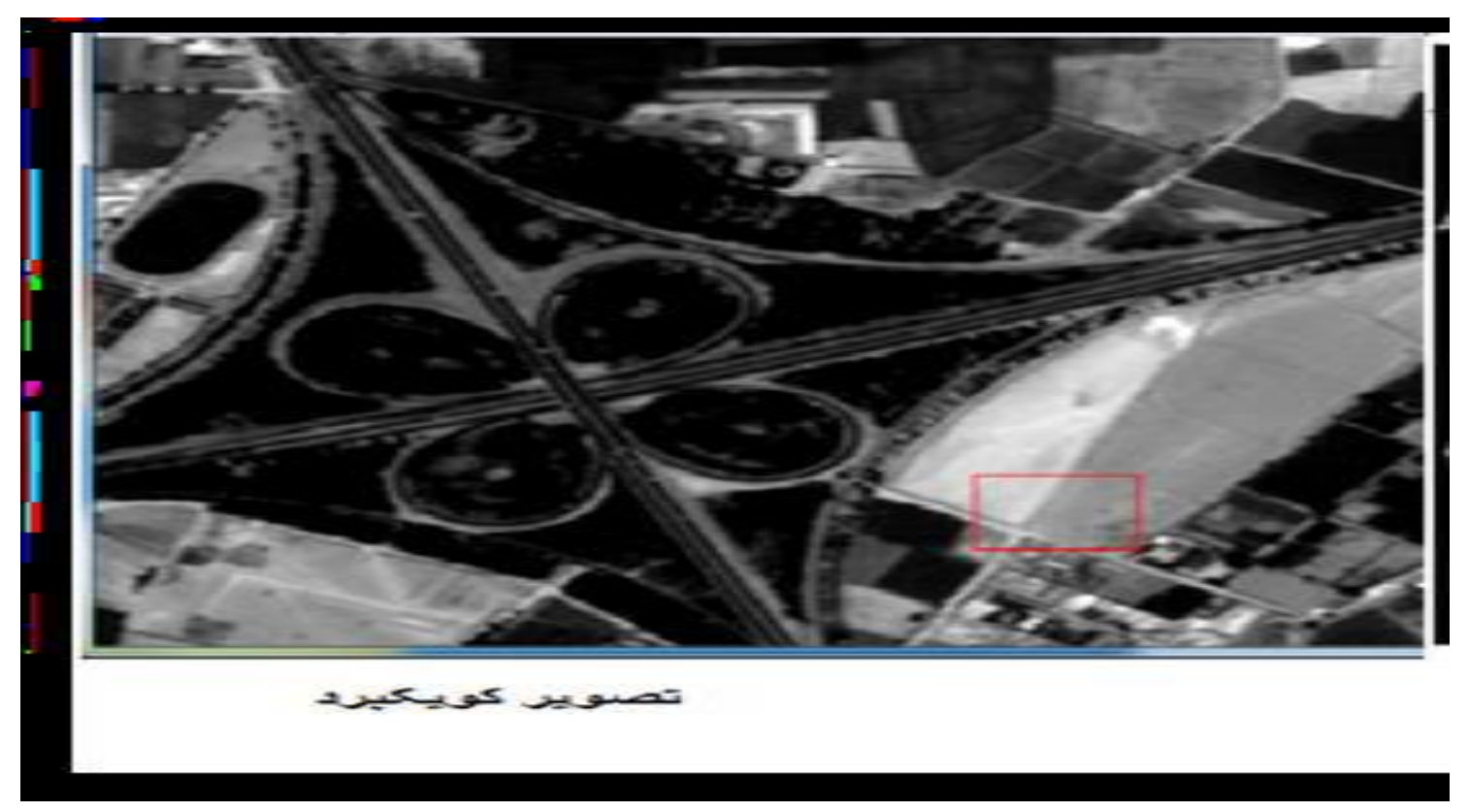

Fig4. Mean Filter

\section{Variance Filter}

In the variance filter, figure (5), the more amount of variance is the better, because variance shows the differences and makes abetter distinction betweenthe phenomena. In this filter, all of the phenomena are almost black and dark. On the border of phenomena, edges are sharp, white and recognizable.

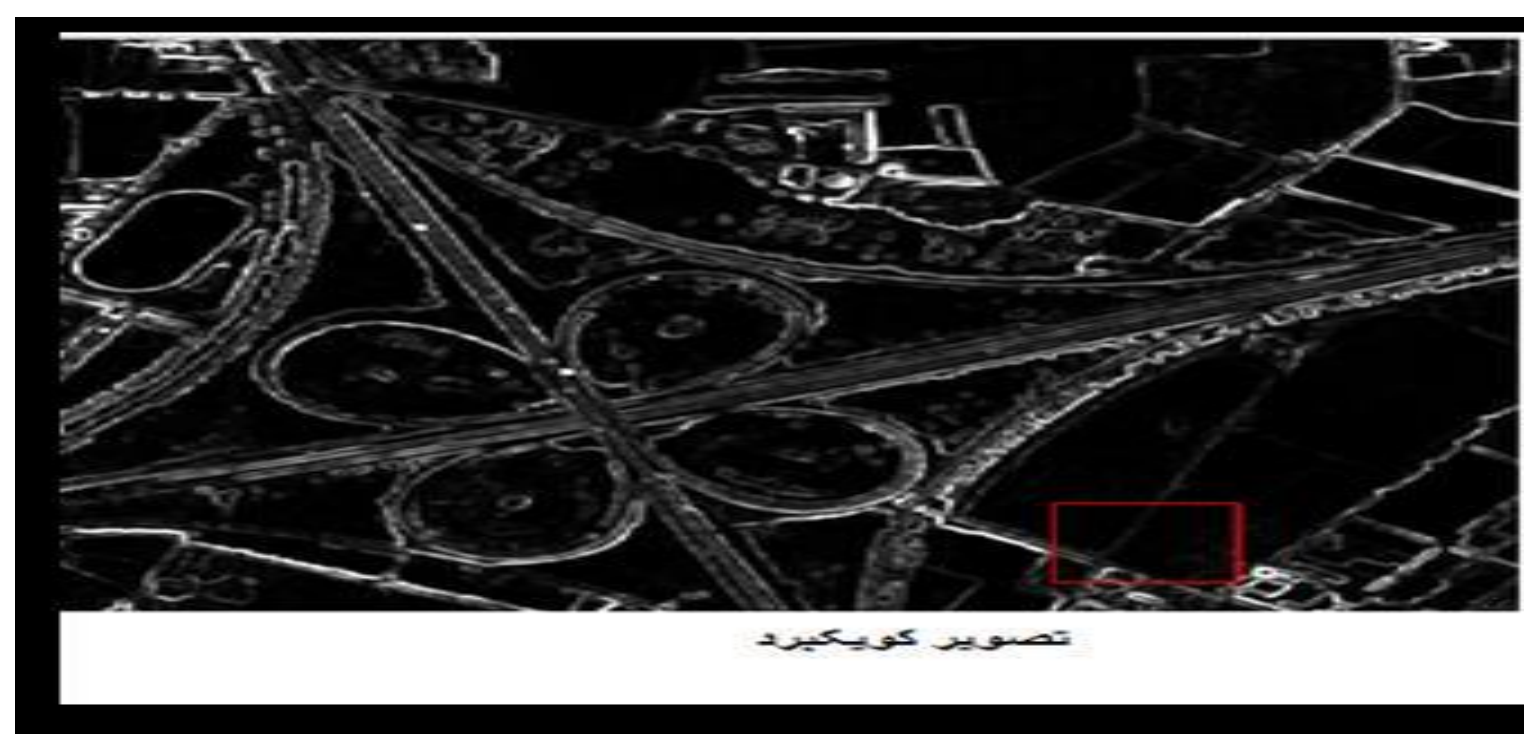

Fig5. Variance Filter

\section{Entropy Filter}

In this filter, figure (6), all of the phenomena are almost white as opposed to shadows and the roofs of the houses which are uniformly black colored. 


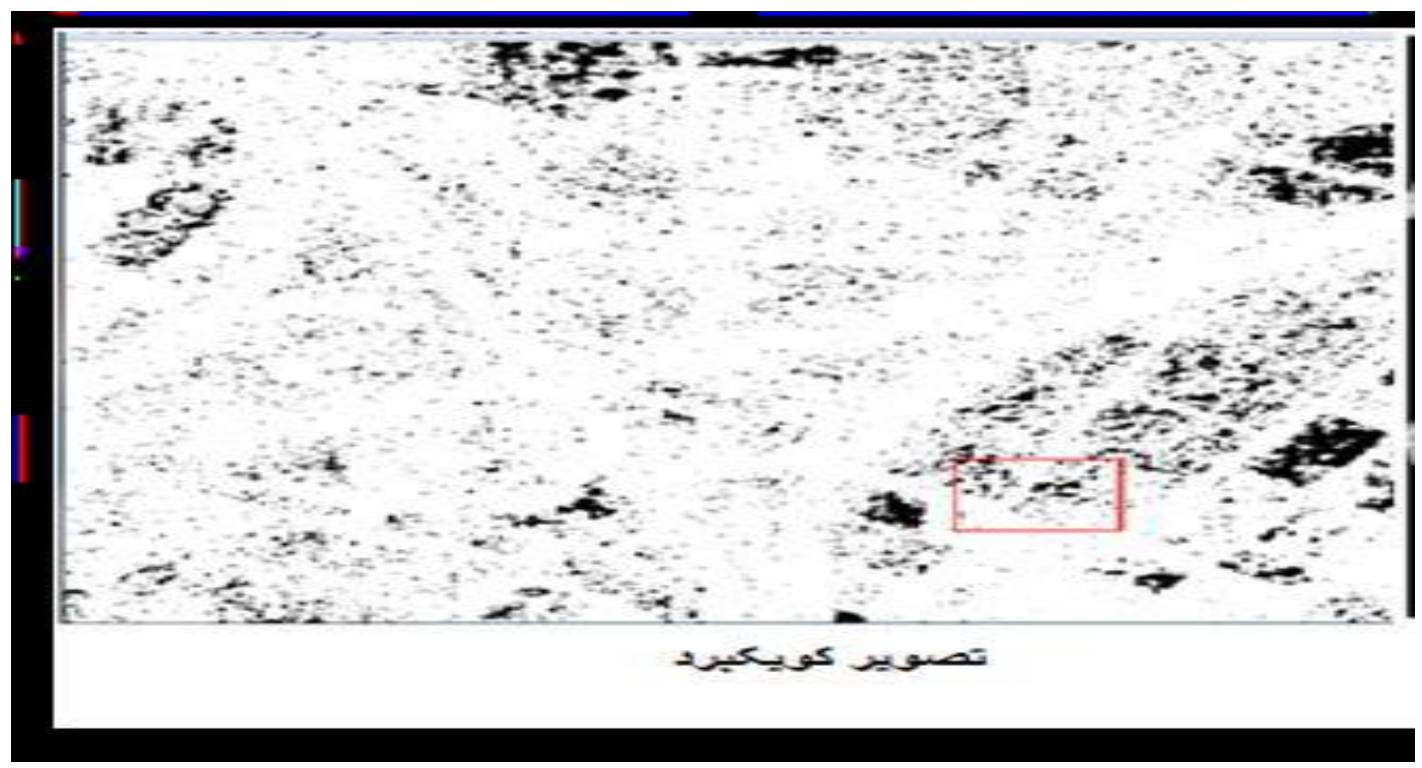

Fig6. Entropy Filter

\section{Training Sample}

To perform classification operations, a training sample was prepared for all the applications. Sampling is done using the software ENVI 4.8. Six classes were defined for sampling. Maximum likelihood classification is one of the most popular methods among pixel-based methods. After performing texture filtering on panchromatic band and images and doing sampling, classification based on maximum likelihood classification was performed. Figure (7). To verify the accuracy of classification, Confusion Matrix tool was used and the resultsare as follows:

Table1. Overall accuracy and Kappa coefficient of classified images using maximum likelihood method

\begin{tabular}{|c|c|c|c|c|}
\hline \multirow{2}{*}{ Satellite Imagery } & \multicolumn{2}{|c|}{ Overall Accuracy } & \multicolumn{2}{c|}{ Kappa Coefficient } \\
\hline & Land Coverage & Greenspace & Land Coverage & Greenspace \\
\hline QuickBird & 0.63 & 0.71 & 0.54 & 0.44 \\
\hline
\end{tabular}
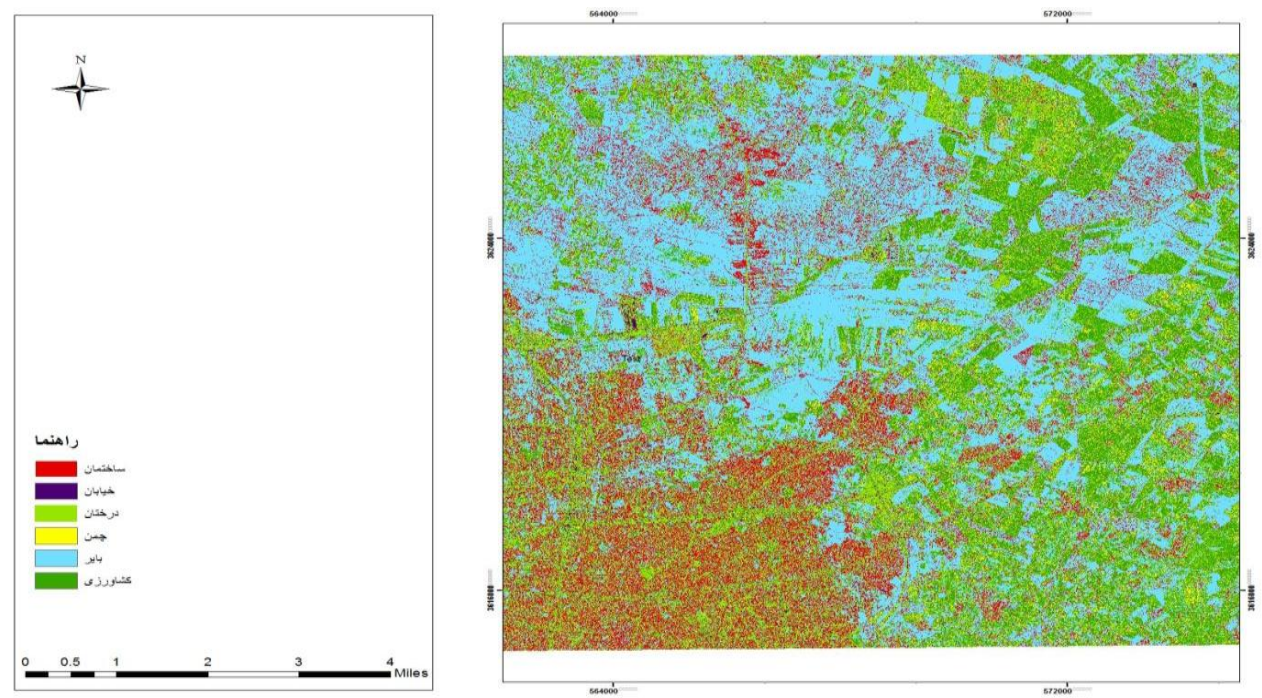

Fig7. Maximum likelihood classification in QuickBird image of Isfahan

\section{Median Filter with A Window size of $3 * 3$ :}

To improve theaccuracy of image classification, amedian filter with awindow size of $3 * 3$ is used. Figure (8). Overall accuracy for land coverage and Kappa coefficient reached 69.62 and 0.61 respectively. In the use of greenspace overall accuracy was increased to 78.0034 and Kappa 
Preparing A Land Cover Map with Emphasis on Green Space (Grass, Tree, Agriculture): by using Image Texture Filters in Panchromatic Band, Iran

coefficient to 0.66 . These results show that the median filter has been effective enough and according to figure (9), the classification accuracy is increased to some extent.
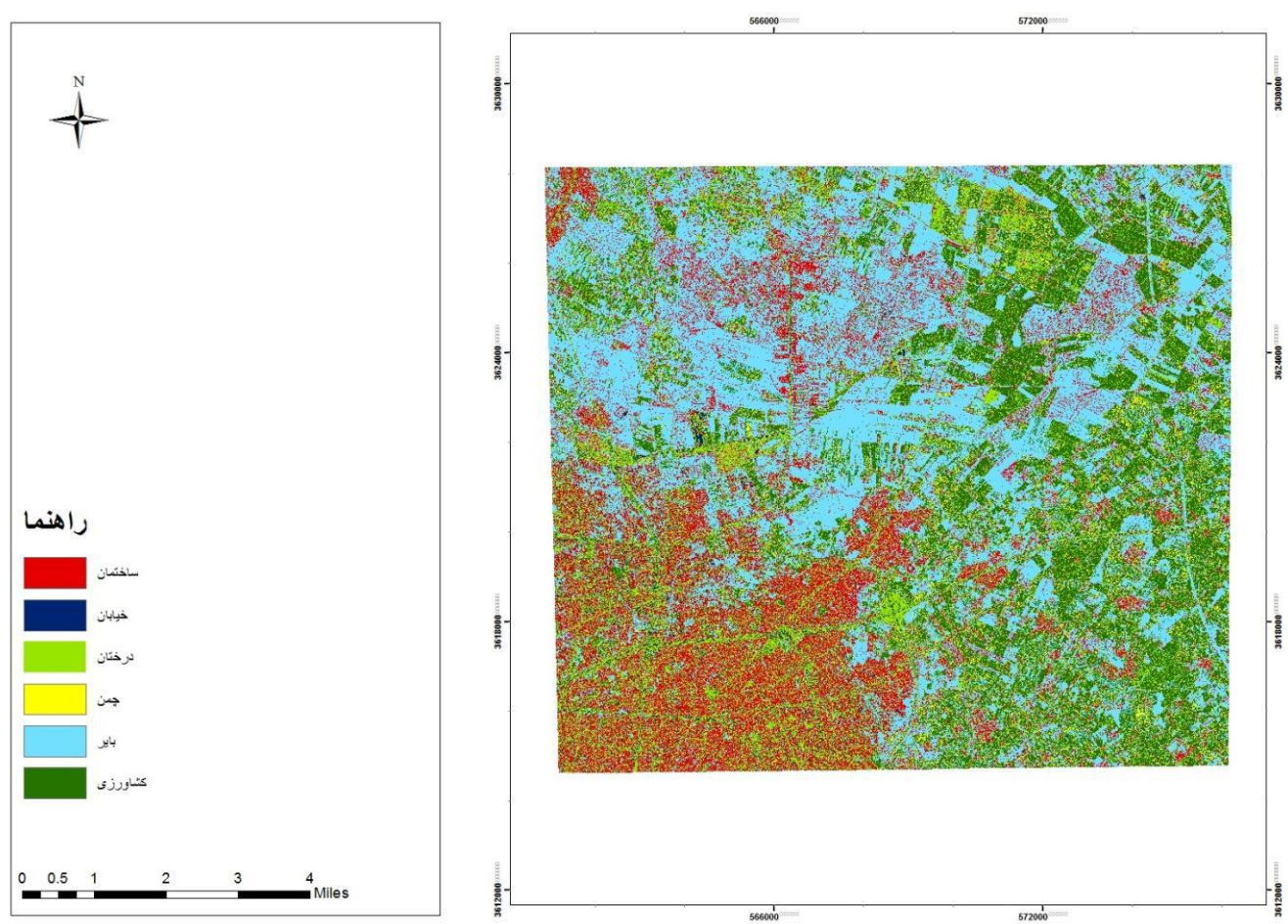

Fi8. Maximum likelihood classification in QuickBird image of Isfahan, with median filter with window size of $3 * 3$

\section{Median Filter with a Window Size of $5 * 5$}

Considering the result of previous step and improvement of land cover classification, median filter with window size of $5 * 5$ was performed on the image, Figure (9), and results are as follows:

The overall accuracy for the land cover of Quick Bird image is 69.62 and for green space is 79.08. The Kappa coefficient also reached 0.61 in land cover and 56 in green space. These results showed that median filter with the window size of $5 * 5$ has a significant effect on the accuracy.
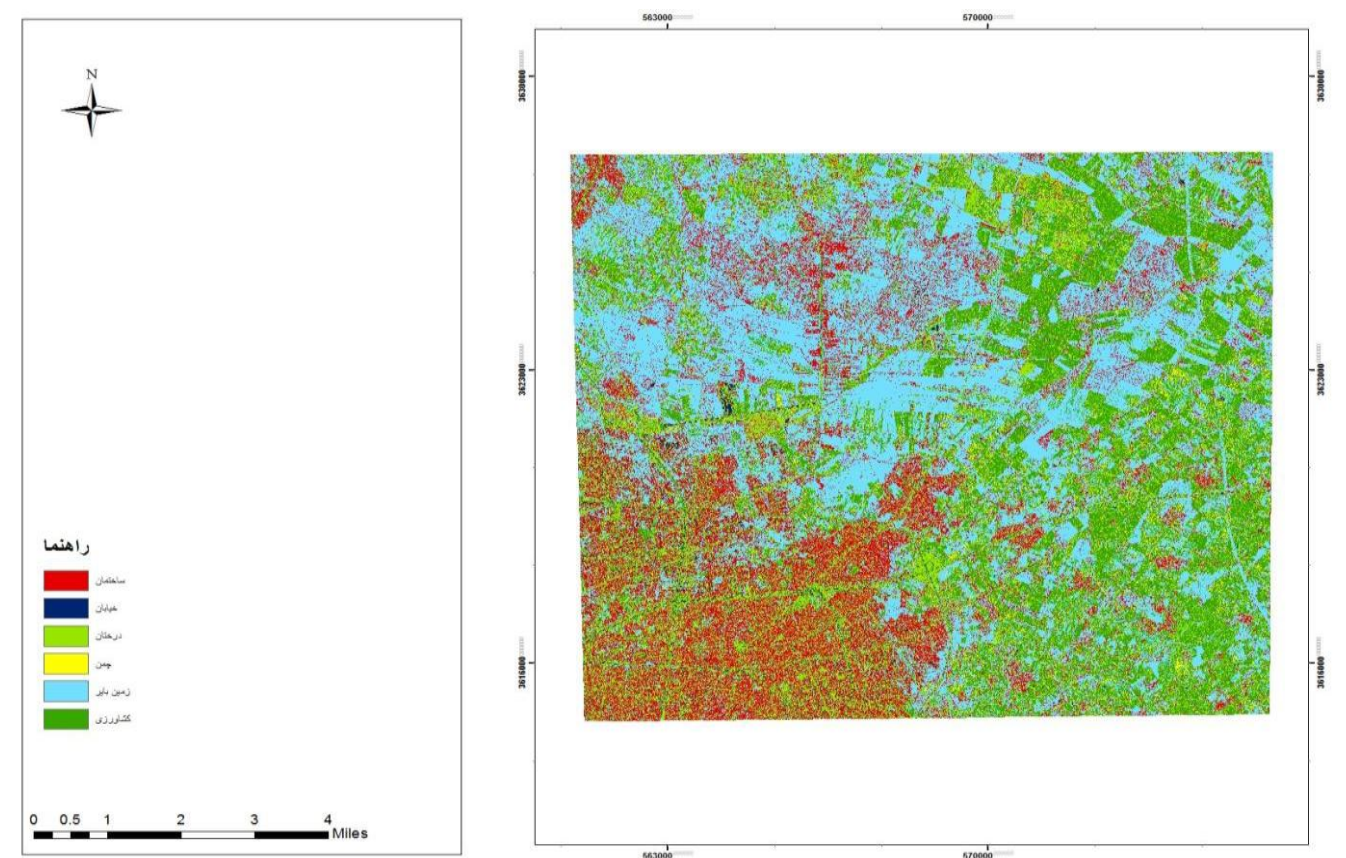

Fig9. Maximum likelihood classification in QuickBird image of Isfahan by performing median filter with window size of $5 * 5$ 


\section{Maximum Likelihood Classification Without Median Filter}

To show the effect of median filter, classification is once done without using it in QuickBird image of Isfahan, according to fig (10), the overall accuracy for maximum likelihood classification is 32.5 and for land coverage and Kappa coefficient is $18 \%$. This classification for urban greenspace is 41 and for Kappa coefficient is $0.07 \%$, therefore, results show the considerable effect of median filter on the accuracy of the classification of land cover.

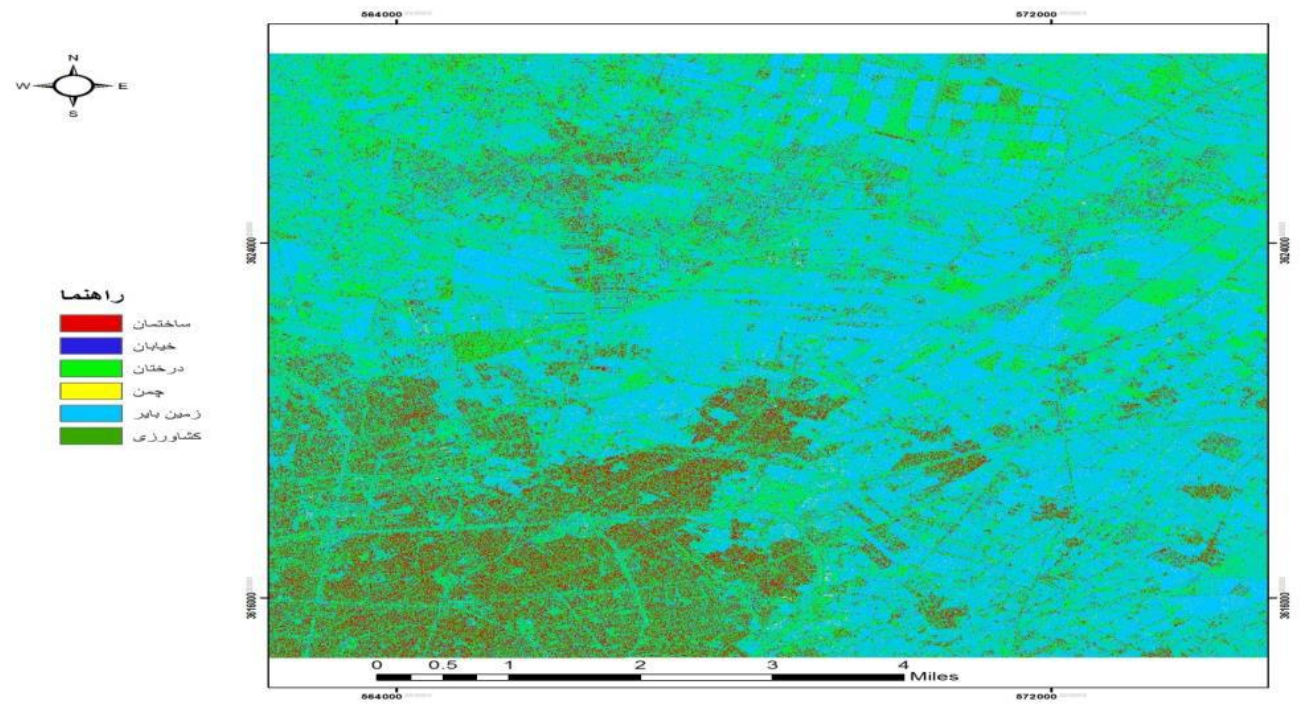

Fig10. Maximum likelihood classification map without median filter

\section{CONCLUSION}

Detailed information on land coverage from urban areas is necessary for many purposes, such as urban land management, urban planning and urban landscape pattern. In order to achieve sustainable development, it is essential to have detailed planning, controlling and managing the changes in the cover function of land, which are a result of natural or artificial phenomena including the manipulation of man. The present study employs Quick Bird panchromatic image band which is more accurate compared to color bands and is often ignored when it comes to categorizing and designing function/land-cover maps. Its accuracy has been compared to the color image and, as it can be seen, the categorizing accuracy in color images equals $86 \%$. In panchromatic band, the accuracy for the six cover/function equals $62.69 \%$ and for the three function of greenspace it equals $79 \%$, which is acceptable accuracy considering the application of filters with a window-size of $5 * 5$ for agricultural lawn cover and tree cover.

\section{REFERENCES}

[1] Ostad-Ali-Askari, K., Shayannejad, M. 2015, Study of sensitivity of Autumnal wheat to under irrigation in Shahrekord, Shahrekord City, Iran. International Journal of Agriculture and Crop Sciences, 8 (4), 602-605.

[2] Shayannejad, M., Akbari, N., Ostad-Ali-Askari, K. 2015, Study of modifications of the river physical specifications on muskingum coefficients, through employment of genetic algorithm. International Journal of Development Research, 5(3), 3782-3785.

[3] Ostad-Ali-Askari, K., Shayannejad, M. 2015, The Reviews of Einstein's Equation of Logarithmic Distribution Platform and the Process of Changes in the Speed Range of the Karkheh River, Khuzestan province, Iran. International Journal of Development Research, 5(3), 3786-3790.

[4] Ostad-Ali-Askari, K., Shayannejad, M., Ghorbanizadee-Kharazi, H. 2015, Assessment of artificial neural network performance and exponential regression in prediction of effective rainfall, International Journal of Development Research, 5(3),3791-3794.

[5] Shayannejad, M. Akbari, N. and Ostad-Ali-Askari, K. 2015, Determination of the nonlinear Muskingum model coefficients using genetic algorithm and numerical solution of the continuity. Int. J. of Science: Basic and Applied Research, 21(1),1-14.

[6] Ostad-Ali-Askari, K., Shayannejad, M. 2015, The Study of Mixture Design for Foam Bitumen and the Polymeric and Oil Materials Function in Loose Soils Consolidation. Journal of Civil Engineering Research, 5(2), 39-44. DOI: 10.5923/j.jce.20150502.04 
[7] Sayedipour, M., Ostad-Ali-Askari, K., Shayannejad, M. 2015, Recovery of Run off of the Sewage Refinery, a Factor for Balancing the Isfahan-Borkhar Plain Water Table in Drought Crisis Situation in Isfahan Province-Iran. American Journal of Environmental Engineering, 5(2): 43-46. DOI: 10.5923/j.ajee.20150502.02

[8] Ostad-Ali-Askari, K., Shayannejad, M. 2015, Developing an Optimal Design Model of Furrow Irrigation Based on the Minimum Cost and Maximum Irrigation Efficiency. International Bulletin of Water Resources \& Development, 3(2), 18-23.

[9] Ostad-Ali-Askari, K., Shayannejad, M. 2015, Presenting a Mathematical Model for Estimating the Deep Percolation Due to Irrigation. International Journal of Hydraulic Engineering, 4(1), 17-21. DOI: 10.5923/j.ijhe.20150401.03.

[10] Ostad-Ali-Askari, K., Shayannejad, M. 2015, Usage of rockfill dams in the HEC-RAS software for the purpose of controlling floods. American Journal of Fluid Dynamics, 5(1), 23-29. DOI: 10.5923/j.ajfd.20150501.03.

[11] Ostad-Ali- Askari, K., Shayannejad, M. 2015, The effect of heterogeneity due to inappropriate tillage on water advance and recession in furrow irrigation. Journal of Agricultural Science, 7(6), 127-136.

[12] Shayannejad, M., Ostad-Ali-Askari, K. 2015, Effects of magnetized municipal effluent on some chemical properties of soil in furrow irrigation. International Journal of Agriculture and Crop Sciences, 8(3), 482489.

[13] Ostad-Ali-Askari, K., Shayannejad, M. 2015, Optimal design of pressurized irrigation laterals installed on sloping land. International Journal of Agriculture and Crop Sciences, ISSN 2227-670X. 8(5), 792-797.

[14] Ostad-Ali-Askari K, Shayannejad M, Eslamian S, Navab-Pour B. 2016, Comparison of solution of SaintVenant equations by characteristics and finite difference methods for unsteady flow analyzing in open channel. International Journal of Hydrology Science and Technology, 6(3), 9-18.

[15] Ostad-Ali-Askari K, Shayannejad M, Eslamian S, et al. 2017, Deficit Irrigation: Optimization Models. Management of Drought and Water Scarcity. Handbook of Drought and Water Scarcity, Taylor \& Francis Publisher, USA. Vol. 3. $1^{\text {th }}$ Edition, pp: 373-389.

[16] Shayannejad M, Ostad-Ali-Askari K, Eslamian S, et al. 2017, Development of a new method for determination of infiltration coefficients in furrow irrigation with natural non-uniformity of slope. Sustain. Water Resour. Manag., 3(2): 163-169.

[17] Shojaei N, Shafaei-Bejestan M, Eslamian S, Marani-Barzani M, P. Singh V, Kazemi M, Ostad-Ali-Askari K. 2017, Assessment of Drainage Slope on the Manning Coarseness Coefficient in Mountain Area. International Journal of Constructive Research in Civil Engineering (IJCRCE), 3(1): 33-40.

[18] Bahmanpour H, Awhadi S, Enjili J, Eslamian S, Ostad-Ali-Askari K. 2017, Optimizing Absorbent Bentonite and Evaluation of Contaminants Removal from Petrochemical Industries Wastewater. International Journal of Constructive Research in Civil Engineering (IJCRCE), 3(2): 34-42.

[19] Shayannejad M, Eslamian S, Gandomkar A, Marani-Barzani M, Amoushahi-Khouzani M, Majidifar Z, Rajaei-Rizi F, Kazemi M, P. Singh V, Dehghan SH, Shirvani-Dastgerdi H.R, Norouzi H, Ostad-Ali-Askari K. 2017, A Proper Way to Install Trapezoidal Flumes for Measurements in Furrow Irrigation Systems. International Journal of Research Studies in Agricultural Sciences (IJRSAS), 3(7): 1-5.

[20] Dehghan Sh, Kamaneh S.A.A., Eslamian S, Gandomkar A, Marani-Barzani M, Amoushahi-Khouzani M, Singh V.P., Ostad-Ali-Askari K. 2017, Changes in Temperature and Precipitation with the Analysis of Geomorphic Basin Chaos in Shiraz, Iran. International Journal of Constructive Research in Civil Engineering (IJCRCE), 3(2): 50-57.

[21] Ostad-Ali-Askari K, Shayannejad M. 2016, FLOOD ROUTING IN RIVERS BY MUSKINGUM'S METHOD WITH NEW ADJUSTED COEFFICIENTS. International Water Technology Journal, IWTJ, 6(3): 189-194.

[22] Ostad-Ali-Askari K, Shayannejad M, Ghorbanizadeh-Kharazi H. 2017, Artificial Neural Network for Modeling Nitrate Pollution of Groundwater in Marginal Area of Zayandeh-rood River, Isfahan, Iran. KSCE Journal of Civil Engineering, 21(1):134-140. Korean Society of Civil Engineers. DOI 10.1007/ s12205-016-0572-8.

[23] Shayannejad M, Ostad-Ali-Askari K, Ramesh A, Singh V.P., Eslamian S. 2017, Wastewater and Magnetized Wastewater Effects on Soil Erosion in Furrow Irrigation. International Journal of Research Studies in Agricultural Sciences (IJRSAS), 3(8): 1-14. http://dx.doi.org/10.20431/2454-6224.0308001.

[24] Shayannejad M, Soltani-Toudeshki A.R, Arab M.A, Eslamian S, Amoushahi-Khouzani M, MaraniBarzani M, Ostad-Ali-Askari K. 2017, A Simple Method for Land Grading Computations and its Comparison with Genetic Algorithm (GA) Method. International Journal of Research Studies in Agricultural Sciences (IJRSAS), 3(8): 26-38. 
[25] Mohieyimen P, Eslamian S, Ostad-Ali-Askari K, Soltani M. 2017,Climate Variability: Integration of Renewable Energy into Present and Future Energy Systems in Designing Residential Buildings. International journal of Rural Development, Environment and Health Research(IJREH), 1(2): 18-30.

[26] Shayannejad M, Ostad-Ali-Askari K, Eslamian S, et al. 2017, Flow Hydraulic Investigation of the Wastewater on the Soil and Magnetic Field Effects in This Field. International Journal of Constructive Research in Civil Engineering (IJCRCE), 3(3): 1-15.

[27] Shayannejad M, Eslamian S, Singh V.P., Ostad-Ali-Askari K, et al. 2017, Evaluation of Groundwater Quality for Industrial Using GIS in Mountainous Region of Isfahan Province, Koh-Payeh, Isfahan, Iran. International Journal of Constructive Research in Civil Engineering (IJCRCE), 3(3): 24-37.

[28] Eslamian S, P. Singh V, Ostad-Ali-Askari K, R. Dalezios N, Yihdego Y, et al. 2017, Assessment of Aridity Using Geographical Information System in Zayandeh-Roud Basin, Isfahan, Iran. International Journal of Mining Science (IJMS), 3(2): 49-61.

[29] Askari Z, Samadi-Boroujeni H, Fattahi-Nafchi R, Yousefi N, Eslamian S, Ostad-Ali-Askari K, P. Singh V, R. Dalezios N. 2017, Prediction Comparison of Flow Resistance in Channels with Rounded and Angular Coarse Rough Beds. American Research Journal of Civil and Structural, 3(1): 1-15.

[30] Ghane M, Alvankar S.R., Eslamian S, Amoushahi-Khouzani M, Gandomkar A, Zamani E, Marani-Barzani M, Kazemi M, Soltani M, Dehghan SH, P. Singh V, Ostad-Ali-Askari K, HaeriHamedani M, ShirvaniDastgerdi H.R., Zalaki-Badil N. 2017, Sensitivity Analysis of Runoff Model by SWAT to Meteorological Parameters: A Case Study of Kasillian Watershed, Mazandaran, Iran. International Journal of Research Studies in Agricultural Sciences (IJRSAS), 3(10): 1-20.

[31] Shayannejad M, Abedi M.S., Eslamian S, Ostad-AliAskari K, Gandomkar A, Cheng A, et al. 2017, The Contribution of Artificial Charging in Optimal Exploitation of Water Resources, Isfahan, Iran. InternationalJournal of Mining Science (IJMS), 3(3): 9-20.

[32] Eslamian S,Ostad-AliAskari K, et al. 2017, Guidelines to Optimal Design of Furrow Irrigation Based on Plants, Soil and Furrow Specifications. International Journal of Constructive Research in Civil Engineering (IJCRCE), 3(4): 20-39.

[33] Eslamian S, Gandomkar A, Khademolhoseiny A, Ostad-AliAskari K, et al. 2017, The Study on the GeoMorphism Related Characteristics of Shiraz Geomorphic Basin, Fars Province, Iran. International Journal of Mining Science (IJMS), 3(4): 10-23. DOI: http://dx.doi.org/10.20431/2454-9460.0304002

[34] Dalezios, N. R., Spyropoulosand, N. V., Eslamian, S., 2017, Remote Sensing in Drought Quantification and Assessment, Ch. 21 in Handbook of Drought and Water Scarcity, Vol. 1: Principles of Drought and Water Scarcity, Ed. by Eslamian S. and Eslamian F., Francis and Taylor, CRC Press, USA, 377-396.

[35] Araghinejad, S., Hosseini-Moghari, S. M., Eslamian, S., 2017, Application of Data-Driven Models in Drought Forecasting, Ch. 23 in Handbook of Drought and Water Scarcity, Vol. 1: Principles of Drought and Water Scarcity, Ed. by Eslamian S. and Eslamian F., Francis and Taylor, CRC Press, USA, 423-440.

[36] Vafakhah, M., and Eslamian, S., 2017, Application of Intelligent Technology in Rainfall Analysis, Ch. 24 in Handbook of Drought and Water Scarcity, Vol. 1: Principles of Drought and Water Scarcity, Ed. by Eslamian S. and Eslamian F., Francis and Taylor, CRC Press, USA, 441-460.

[37] Vafakhah, M., Akbari Majdar, H. and Eslamian, S., 2017, Rainfall Prediction Using Time Series Analysis, Ch. 28 in Handbook of Drought and Water Scarcity, Vol. 1: Principles of Drought and Water Scarcity, Ed. by Eslamian S. and Eslamian F., Francis and Taylor, CRC Press, USA, 517-540.

[38] González, M. H., Garbarini, E. M., Rolla, A. L., and Eslamian, S., 2017, Meteorological Drought Indices: Rainfall Prediction in Argentina, Ch. 29 in Handbook of Drought and Water Scarcity, Vol. 1: Principles of Drought and Water Scarcity, Ed. by Eslamian S. and Eslamian F., Francis and Taylor, CRC Press, USA, 541-570.

[39] Hadizadeh, R. and Eslamian, S., 2017, Modeling Hydrological Processby ARIMA-GARCH Time Series, Ch. 30 in Handbook of Drought and Water Scarcity, Vol. 1: Principles of Drought and Water Scarcity, Ed. by Eslamian S. and Eslamian F., Francis and Taylor, CRC Press, USA, 571-590.

[40] Mujere, N., Yang, X. and Eslamian, S., 2017, Gradation of Drought-Prone Area, Ch. 31 in Handbook of Drought and Water Scarcity, Vol. 1: Principles of Drought and Water Scarcity, Ed. by Eslamian S. and Eslamian F., Francis and Taylor, CRC Press, USA, 591-606.

[41] Mahmudul Haque, M., Amir Ahmed, A., Rahman, A., Eslamian, S., 2017, Drought Losses to Local Economy, Ch. 33 in Handbook of Drought and Water Scarcity, Vol. 1: Principles of Drought and Water Scarcity, Ed. by Eslamian S. and Eslamian F., Francis and Taylor, CRC Press, USA, 627-642.

[42] Fakhruddin, B. S. H. M., Eslamian, S., 2017, Analysis of Drought Factors Affecting the Economy, Ch. 34 in Handbook of Drought and Water Scarcity, Vol. 1: Principles of Drought and Water Scarcity, Ed. by Eslamian S. and Eslamian F., Francis and Taylor, CRC Press, USA, 643-656. 
[43] Dalezios, N. R., Eslamian, S., 2017, Environmental Impacts of Drought on Desertification Classification,Ch. 3 in Handbook of Drought and Water Scarcity, Vol. 2: Environmental Impacts and Analysis of Drought and Water Scarcity, Ed. by Eslamian S. and Eslamian F., Francis and Taylor, CRC Press, USA, 45-64.

[44] Nazif, S. and Tavakolifar, H., Eslamian, S., 2017, Climate Change Impact on Urban Water Deficit, Ch. 5 in Handbook of Drought and Water Scarcity, Vol. 2: Environmental Impacts and Analysis of Drought and Water Scarcity, Ed. by Eslamian S. and Eslamian F., Francis and Taylor, CRC Press, USA, 81-106.

[45] Shahid, S., Alamgir, M., Wang, X.-J., Eslamian, S., 2017, Climate Change Impacts on and Adaptation to Groundwater,Ch. 6 in Handbook of Drought and Water Scarcity, Vol. 2: Environmental Impacts and Analysis of Drought and Water Scarcity, Ed. by Eslamian S. and Eslamian F., Francis and Taylor, CRC Press, USA, 107-124.

[46] Orimoogunje, O. O. I.,Eslamian, S., 2017, Minimizing the Impacts of Drought, Ch. 8 in Handbook of Drought and Water Scarcity, Vol. 2: Environmental Impacts and Analysis of Drought and Water Scarcity, Ed. by Eslamian S. and Eslamian F., Francis and Taylor, CRC Press, USA, 143-162.

[47] Maleksaeidi, H., Keshavarz, M., Karami, E., Eslamian, S., 2017, Climate Change and Drought: Building Resilience for an Unpredictable Future, Ch. 9 in Handbook of Drought and Water Scarcity, Vol. 2: Environmental Impacts and Analysis of Drought and Water Scarcity, Ed. by Eslamian S. and Eslamian F., Francis and Taylor, CRC Press, USA, 163-186.

[48] Reyhani, M. N.,Eslamian, S., Davari, A., 2017, Sustainable Agriculture: Building Social-Ecological Resilience, Ch. 10 in Handbook of Drought and Water Scarcity, Vol. 2: Environmental Impacts and Analysis of Drought and Water Scarcity, Ed. by Eslamian S. and Eslamian F., Francis and Taylor, CRC Press, USA, 187 -204.

[49] Crusberg, T. C., Eslamian, S., 2017, Drought and Water Quality,Ch. 11 in Handbook of Drought and Water Scarcity, Vol. 2: Environmental Impacts and Analysis of Drought and Water Scarcity, Ed. by Eslamian S. and Eslamian F., Francis and Taylor, CRC Press, USA, 205-218.

[50] Gaaloul, N., Eslamian, S., and Laignel, B.,2017, Contamination of Groundwater in Arid and Semiarid Lands, Ch. 16 in Handbook of Drought and Water Scarcity, Vol. 2: Environmental Impacts and Analysis of Drought and Water Scarcity, Ed. by Eslamian S. and Eslamian F., Francis and Taylor, CRC Press, USA, 291-314.

[51] Banjoko, B., Eslamian, S., 2017, Sanitation in Drought, Ch. 17 in Handbook of Drought and Water Scarcity, Vol. 2: Environmental Impacts and Analysis of Drought and Water Scarcity, Ed. by Eslamian S. and Eslamian F., Francis and Taylor, CRC Press, USA, 315-330.

[52] Davari, A., Bagheri, A., Reyhani, M. N.,Eslamian, S., 2017, Environmental Flows Assessment in Scarce Water Resources, Ch. 18 in Handbook of Drought and Water Scarcity, Vol. 2: Environmental Impacts and Analysis of Drought and Water Scarcity, Ed. by Eslamian S. and Eslamian F., Francis and Taylor, CRC Press, USA, 331-352.

[53] Qian, Q., Eslamian, S., 2017, Streamflow Quality in Low-Flow Conditions, Ch. 20 in Handbook of Drought and Water Scarcity, Vol. 2: Environmental Impacts and Analysis of Drought and Water Scarcity, Ed. by Eslamian S. and Eslamian F., Francis and Taylor, CRC Press, USA, 375-386.

[54] Mohammadzade Miyab, N., Eslamian, S., Dalezios, N. R., 2017, River Sediment in Low Flow Condition, Ch. 21 in Handbook of Drought and Water Scarcity, Vol. 2: Environmental Impacts and Analysis of Drought and Water Scarcity, Ed. by Eslamian S. and Eslamian F., Francis and Taylor, CRC Press, USA, 387-408.

[55] Pérez-Blanco, C. D., Delacámara., G., Gómez., C. M., Eslamian, S., 2017, Crop Insurance in Drought Conditions, Ch. 23 inHandbook of Drought and Water Scarcity, Vol. 2: Environmental Impacts and Analysis of Drought and Water Scarcity, Ed. by Eslamian S. and Eslamian F., Francis and Taylor, CRC Press, USA, 423-444.

[56] Kahrizi, D., Esfahani, K., Ashraf Mehrabi, A., Ghaheri, M., Azizi Aram, Z., Khosravi, S., Eslamian, S., 2017, Biotechnology for Drought Improvement, Ch. 24 in Handbook of Drought and Water Scarcity, Vol. 2: Environmental Impacts and Analysis of Drought and Water Scarcity, Ed. by Eslamian S. and Eslamian F., Francis and Taylor, CRC Press, USA, 445-460.

[57] Wade, P., Eslamian, S., 2017, Water Issues from a System Dynamics Perspective, Ch. 25 in Handbook of Drought and Water Scarcity, Vol. 2: Environmental Impacts and Analysis of Drought and Water Scarcity, Ed. by Eslamian S. and Eslamian F., Francis and Taylor, CRC Press, USA, 461-488.

[58] Rahman, A., Hajani, E., Eslamian, S., 2017, Rainwater Harvesting in Arid Regions of Australia, Ch. 26 in Handbook of Drought and Water Scarcity, Vol. 2: Environmental Impacts and Analysis of Drought and Water Scarcity, Ed. by Eslamian S. and Eslamian F., Francis and Taylor, CRC Press, USA, 489-500. 
[59] Dayani, S., Sabzalian, M. R., Hadipour, M. Eslamian, S., 2017, Water Scarcity and Sustainable Urban Green Landscape, Ch. 30 in Handbook of Drought and Water Scarcity, Vol. 2: Environmental Impacts and Analysis of Drought and Water Scarcity, Ed. by Eslamian S. and Eslamian F., Francis and Taylor, CRC Press, USA, 557-604.

[60] Gohari, A., Zareian, M. J., Eslamian, S., Nazari, R. 2017, Interbasin Transfers of Water: Zayandeh-Rud River Basin, Ch. 32 in Handbook of Drought and Water Scarcity, Vol. 2: Environmental Impacts and Analysis of Drought and Water Scarcity, Ed. by Eslamian S. and Eslamian F., Francis and Taylor, CRC Press, USA, 619-630.

[61] Banjoko, B., Eslamian, S., 2017, Environmental Evaluation: Lessons Learned from Case Studies, Ch. 33 in Handbook of Drought and Water Scarcity, Vol. 2: Environmental Impacts and Analysis of Drought and Water Scarcity, Ed. by Eslamian S. and Eslamian F., Francis and Taylor, CRC Press, USA, 631-664.

[62] Abbasova, D., Eslamian, S., Nazari, R., 2017, Paleo-Drought: Measurements and Analysis, Ch. 34 in Handbook of Drought and Water Scarcity, Vol. 2: Environmental Impacts and Analysis of Drought and Water Scarcity, Ed. by Eslamian S. and Eslamian F., Francis and Taylor, CRC Press, USA, 665-674.

[63] Yihdego, Y.,Eslamian, S., 2017, Drought Management: Initiatives and Objectives, Ch. 1 in Handbook of Drought and Water Scarcity, Vol. 3: Management of Drought and Water Scarcity, Ed. by Eslamian S. and Eslamian F., Francis and Taylor, CRC Press, USA, 1-26.

[64] Tuncok, I. K., Eslamian, S., 2017, Drought Management Strategies in Water-Stressed/Water-Scarce Regions, Ch. 5 in Handbook of Drought and Water Scarcity, Vol. 3: Management of Drought and Water Scarcity, Ed. by Eslamian S. and Eslamian F., Francis and Taylor, CRC Press, USA, 97-154.

[65] Reinstädtler, S., Islam, S. N., Eslamian, S., 2017, Drought Management for Landscape and Rural Security, Ch. 8 in Handbook of Drought and Water Scarcity, Vol. 3: Management of Drought and Water Scarcity, Ed. by Eslamian S. and Eslamian F., Francis and Taylor, CRC Press, USA, 195-234.

[66] Dalezios, N. R.,Eslamian, S., 2017, Drought Assessment and Management for Heat Waves Monitoring, Ch. 9 in Handbook of Drought and Water Scarcity, Vol. 3: Management of Drought and Water Scarcity, Ed. by Eslamian S. and Eslamian F., Francis and Taylor, CRC Press, USA, 235-260.

[67] Kruse, E., Eslamian, S., 2017, Groundwater Management in Drought Conditions, Ch. 11 in Handbook of Drought and Water Scarcity, Vol. 3: Management of Drought and Water Scarcity, Ed. by Eslamian S. and Eslamian F., Francis and Taylor, CRC Press, USA, 275-282.

[68] Araghinejad, S., Hosseini-Moghari, S.-M., Eslamian, S., 2017, Reservoir Operation during Drought, Ch. 12 in Handbook of Drought and Water Scarcity, Vol. 3: Management of Drought and Water Scarcity, Ed. by Eslamian S. and Eslamian F., Francis and Taylor, CRC Press, USA, 283-292.

[69] Eslamian, S., Khosravi, B., Sayahi, M., Haeri-Hamedani, M. 2017, Crises Management Planning and Drought Management Plans, Ch. 13 in Handbook of Drought and Water Scarcity, Vol. 3: Management of Drought and Water Scarcity, Ed. by Eslamian S. and Eslamian F., Francis and Taylor, CRC Press, USA, 293-304.

[70] Halbac-Cotoara-Zamfir, R.,Eslamian, S., 2017, Functional Analysis of Regional Drought Management, Ch. 14 in Handbook of Drought and Water Scarcity, Vol. 3: Management of Drought and Water Scarcity, Ed. by Eslamian S. and Eslamian F., Francis and Taylor, CRC Press, USA, 305-328.

[71] Zahraei, A., Saadati, S., Eslamian, S., 2017, Irrigation Deficit: Farmlands, Ch. 16 in Handbook of Drought and Water Scarcity, Vol. 3: Management of Drought and Water Scarcity, Ed. by Eslamian S. and Eslamian F., Francis and Taylor, CRC Press, USA, 343-358.

[72] Amiri, M. J., Eslamian, S., Bahrami, M., Yousefi, N.2017, Deficit Irrigation: Greenhouse, Ch. 17 in Handbook of Drought and Water Scarcity, Vol. 3: Management of Drought and Water Scarcity, Ed. by Eslamian S. and Eslamian F., Francis and Taylor, CRC Press, USA, 359-372.

[73] Ostad-Ali-Askari, K., Shayanejad, M., Eslamian, S., Zamani, F., Shojaei, N., Navabpour, B., Majidifard, Z., Sadri, A., Ghasemi-Siani, Z., Nourozi, H., Vafaei, O., Homayouni. S.-M.-A., 2017, Deficit Irrigation: Optimization Models, Ch. 18 in Handbook of Drought and Water Scarcity, Vol. 3: Management of Drought and Water Scarcity, Ed. by Eslamian S. and Eslamian F., Francis and Taylor, CRC Press, USA, 373-390.

[74] Eludoyin, A. O., Eludoyin, O. M.,Eslamian, S., 2017, Drought Mitigation Practices, Ch. 19 in Handbook of Drought and Water Scarcity, Vol. 3: Management of Drought and Water Scarcity, Ed. by Eslamian S. and Eslamian F., Francis and Taylor, CRC Press, USA, 391-402

[75] Irshad, S. M.,Eslamian, S., 2017, Politics of Drought Management and Water Control in India, Ch. 22 in Handbook of Drought and Water Scarcity, Vol. 3: Management of Drought and Water Scarcity, Ed. by Eslamian S. and Eslamian F., Francis and Taylor, CRC Press, USA, 447-460.

[76] Pati, R.,Eslamian, S., 2017, Drought Management for Horticultural Crops in India, Ch. 23 in Handbook of Drought and Water Scarcity, Vol. 3: Management of Drought and Water Scarcity, Ed. by Eslamian S. and Eslamian F., Francis and Taylor, CRC Press, USA, 461-482. 
[77] Khan, S., Eslamian, S., 2017, , Ch. 25 in Handbook of Drought and Water Scarcity, Vol. 3: Management of Drought and Water Scarcity, Ed. by Eslamian S. and Eslamian F., Francis and Taylor, CRC Press, USA, 495-526.

[78] Sedaei, L., Sedaei, N., Cox, J. P., Dalezios N. R., Eslamian, S., 2017, Forest Fire Mitigation under Water Shortage, Ch. 26 in Handbook of Drought and Water Scarcity, Vol. 3: Management of Drought and Water Scarcity, Ed. by Eslamian S. and Eslamian F., Francis and Taylor, CRC Press, USA, 527-550.

[79] Torabi Farsani, N., Neto de Carvalho, C., Eslamian, S., 2017, Education Program for Drought, Ch. 27 in Handbook of Drought and Water Scarcity, Vol. 3: Management of Drought and Water Scarcity, Ed. by Eslamian S. and Eslamian F., Francis and Taylor, CRC Press, USA, 551-566.

[80] Nazif, S. and Tavakolifar, H.,Eslamian, S., 2017,Emergency Drought Consequence Plan, Ch. 30 in Handbook of Drought and Water Scarcity, Vol. 3: Management of Drought and Water Scarcity, Ed. by Eslamian S. and Eslamian F., Francis and Taylor, CRC Press, USA, 640-658

[81] Mohseni Saravi, M., Shabazi, R., Eslamian, S., 2017,Coping with Drought- Ch. 31 in Handbook of Drought and Water Scarcity, Vol. 3: Management of Drought and Water Scarcity, Ed. by Eslamian S. and Eslamian F., Francis and Taylor, CRC Press, USA, 659-673

[82] Eslamian, S., Mohri-Isfahani, E., Mahdavi, A., Rajaei-Rizi, F., Marzi-Nouhedani, M., Ghasemi-Zanyani, M., Dehghani, S., Hosseini-Teshnizi' S. Z., Esmaeili, F., Shojaei, N., Ghane, M., Hasantabar-Amiri, A., 2017, Integrated Water Resources Management Under Water Scarcity, Ch. 32 in Handbook of Drought and Water Scarcity, Vol. 3: Management of Drought and Water Scarcity, Ed. by Eslamian S. and Eslamian F., Francis and Taylor, CRC Press, USA, 675-695.

[83] Aghaei, A., Eslamian, S., Dalezios, N. R., Saeidi-Rizi, A., Bahrebardar, S., 2017, Drought and Dust Management, Ch. 33 in Handbook of Drought and Water Scarcity, Vol. 3: Management of Drought and Water Scarcity, Ed. by Eslamian S. and Eslamian F., Francis and Taylor, CRC Press, USA, 696-705.

[84] Eslamian, S., Davari, A., and Reyhani, M. N., 2017, Iranian Qanāts: An Ancient and Sustainable Water Resources Utilization, Ch. 9, in Underground Aqueducts Handbook, Ed. By Angelakis A. N. et al., Taylor and Francis, CRC Group, 123-150.

[85] Khan, S., and Eslamian, S., 2017, Managing Drought through Qanāt and Water Conservation in Afghanistan, Ch. 22, in Underground Aqueducts Handbook, Ed. By Angelakis A. N. et al., Taylor and Francis, CRC Group, 385-402.

[86] Wessels, J. I., Vardakos, S., Weingartner, H., Eslamian, S., Angelakis, A. N., 2017, Underground Aqueducts: Past, Present, and Future Trends, Ch. 29 in Underground Aqueducts Handbook, Ed. By Angelakis A. N. et al., Taylor and Francis, CRC Group, 491-510.

[87] Dalezios, N.R., Tarquis, A. M. and Eslamian, S. 2017: Droughts. Chapter 5, in book: Environmental Hazards Methodologies for RiskAssessment and Management. Editor: Dalezios, N. R., International Water Association Publishing,London, UK, 177-210.

[88] Dalezios, N. R. and Eslamian, S, 2017, Environmental Hazards Methodologies for Risk Assessment and Management, Ed. By Dalezios, N. R., IWA Publishing,

[89] Bazrkar, M. H., Adamowski, J., Eslamian, S., 2017, Water System Modeling, in Mathematical Advances Towards Sustainable Environmental Systems, Ed.by Furze, J.N., Swing, K., Gupta, A.K., McClatchey, R., Reynolds, D.,Springer International Publishing, Switzerland, 61-88.

[90] Zareeian, M.J., Eslamian, S., Gohari, A., and Adamowski, J.2017. The Effect of Climate Change on Watershed Water Balance, in Mathematical Advances Towards Sustainable Environmental Systems, Ed.by Furze, J.N., Swing, K., Gupta, A.K., McClatchey, R., Reynolds, D.,Springer International Publishing, Switzerland, 215-238.

[91] Bazrkar, M. H., Zamani, N., Eslamian, S., Eslamian, A., Dehghan, Z., 2015, Urbanization and Climate Change, Handbook of Climate Change Adaptation, Ed. By Leal Filho, W., Springer, 619-655.

[92] Gohari, A., Zareeian, M. J. and Eslamian, S., 2015, A multi-model framework for climate change impact assessment, Handbook of Climate Change Adaptation, Ed. By Leal Filho, W., Springer, 17-35.

[93] Chen, Z., Ngo, H. H., Guo,W, and Eslamian, S., 2015, Water Shortages, in Urban Water Reuse Handbook, Ch. 1, Ed. By Eslamian, S., Taylor and Francis, CRC Group, USA, 3-14.

[94] Boogaard, F. and Eslamian, S., 2015, Water Reuse and Sustainable Urban Drainage Systems, in Urban Water Reuse Handbook, Ch. 4, Ed. By Eslamian, S., Taylor and Francis, CRC Group, USA, 37-44.

[95] Shah Naqvi, S. A. A., Sultan, A., and Eslamian, S., 2015, Water Quality Issues in Urban Water, in Urban Water Reuse Handbook, Ch. 8, Ed. By Eslamian, S., Taylor and Francis, CRC Group, USA, 99-112.

[96] Kumar Singh, Ch., Jha, N., and Eslamian, S., 2015, Reuse, Potable Water, and Possibilities, in Urban Water Reuse Handbook, Ch. 9, Ed. By Eslamian, S., Taylor and Francis, CRC Group, USA, 113-126. 
[97] Kohansal, M. M., Saadati, S., Tarkesh Esfahany, S., and Eslamian, S., 2015, Urban Water Reuse in Industry, in Urban Water Reuse Handbook, Ch. 11, Ed. By Eslamian, S., Taylor and Francis, CRC Group, USA, 137-148.

[98] Kumar, M., Chidambaram, S., Ramanathan, A. L., Goswami, R., and Eslamian, S., 2015, Criterion, Indices, and Classification of Water Quality and Water Reuse Options, Urban Water Reuse Handbook, Ch. 13, Ed. By Eslamian, S., Taylor and Francis, CRC Group, USA, 163-176.

[99] Eslamian, F., Eslamian, S., and Eslamian, A., 2015, Water Reuse Guidelines for Agriculture, Urban Water Reuse Handbook, Ch. 14, Ed. By Eslamian, S., Taylor and Francis, CRC Group, USA, 177-186.

[100]Eslamian, A., Eslamian, F., and Eslamian, S., 2015, Water Reuse Guidelines for Industry, Urban Water Reuse Handbook, Ch. 15, Ed. By Eslamian, S., Taylor and Francis, CRC Group, USA, 187-194.

[101]Eslamian, S., Eslamian, F., and Eslamian, A., 2015, Water Reuse Guidelines for Recreation, Urban Water Reuse Handbook, Ch. 16, Ed. By Eslamian, S., Taylor and Francis, CRC Group, USA, 195-200.

[102]Banjoko, B. and Eslamian, S., 2015, Environmental Impact Assessment: An Application to Urban Water Reuse, Urban Water Reuse Handbook, Ch. 20, Ed. By Eslamian, S., Taylor and Francis, CRC Group, USA, 229-242.

[103]Amiri, M. J., Eslamian, S., Arshadi, M., and Khozaei, M., 2015, Water Recycling and Community, Urban Water Reuse Handbook, Ch. 22, Ed. By Eslamian, S., Taylor and Francis, CRC Group, USA, 261-274.

[104]Ferdaush, J., Noor Islam, Sh., Reinstädtler, S., and Eslamian, S., 2015, Ethical and Cultural Dimension of Water Reuse, Urban Water Reuse Handbook, Ch. 24, Ed. By Eslamian, S., Taylor and Francis, CRC Group, 285-296.

[105]Bazrkar, M. H., Zamani, N., and Eslamian, S., 2015, Evaluation of Socioeconomic Impacts of Urban Water Reuse Using System Dynamics Approach, Urban Water Reuse Handbook, Ch. 28, Ed. By Eslamian, S., Taylor and Francis, CRC Group, 331-340.

[106]Mujere, N. and Eslamian, S., 2015, Blackwater System, Urban Water Reuse Handbook, Ch. 33, Ed. By Eslamian, S., Taylor and Francis, CRC Group, 393-404.

[107]Abu-Ghunmi, L., and Eslamian, S., 2015, Graywater, Urban Water Reuse Handbook, Ch. 34, Ed. By Eslamian, S., Taylor and Francis, CRC Group,405-420.

[108]Eslamian, S., Amininezhad, S. M., and Amininejad, S. M., 2015, Contamination Warning System, Urban Water Reuse Handbook, Ch. 39, Ed. By Eslamian, S., Taylor and Francis, CRC Group, 481-488.

[109]Crusberg, T. C., and Eslamian, S., 2015, Choosing Indicators of Fecal Pollution for Wastewater Reuse Opportunities, Urban Water Reuse Handbook, Ch. 42, Ed. By Eslamian, S., Taylor and Francis, CRC Group, 511-520.

[110]Boogaard, F. and Eslamian, S, 2015, Wastewater Monitoring, Urban Water Reuse Handbook, Ch. 48, Ed. By Eslamian, S., Taylor and Francis, CRC Group, 583-586.

[111]Mujere, N., and Eslamian, S., 2015, Urban Wetland Hydrology and Water Purification, Urban Water Reuse Handbook, Ch. 50, Ed. By Eslamian, S., Taylor and Francis, CRC Group, 603-616.

[112]Nazif, S., and Eslamian, S., 2015, Urban Wetland Hydrology and Changes, Urban Water Reuse Handbook, Ch. 51, Ed. By Eslamian, S., Taylor and Francis, CRC Group, 617-640.

[113]Banjoko, B., and Eslamian, S., 2015, Phytoremediation, Urban Water Reuse Handbook, Ch. 53, Ed. By Eslamian, S., Taylor and Francis, CRC Group, 657-702.

[114]Rivas Hernández, A., Rivas Acosta, I., and Eslamian, S., .2015, Treatment Wetlands: Fundamentals, Urban Water Reuse Handbook, Ch. 54, Ed. By Eslamian, S., Taylor and Francis, CRC Group, 703-716.

[115]Rahman, A., and Eslamian, S., 2015, Rainwater Tanks as a Means of Water Reuse and Conservation in Urban Areas, Urban Water Reuse Handbook, Ch. 60, Ed. By Eslamian, S., Taylor and Francis, CRC Group, 797-808.

[116]Qian, Q., and Eslamian, S., 2015, Groundwater Recharge and Unconventional Water: Design and Management Criteria, Urban Water Reuse Handbook, Ch. 61, Ed. By Eslamian, S., Taylor and Francis, CRC Group, 809-816.

[117]Saket, R. K. and Eslamian, S., 2015, Use of Wastewater for Hydroelectric Power Generation, Urban Water Reuse Handbook, Ch. 63, Ed. By Eslamian, S., Taylor and Francis, CRC Group, 827-838.

[118]Eslamian, S., Amininezhad, S. M., Amininejad, S. M., Adamowski, J., 2015, Application of Nanotechnology in Water Reuse, Urban Water Reuse Handbook, Ch. 64, Ed. By Eslamian, S., Taylor and Francis, CRC Group, 839-844.

[119]Goodarzi, E., Ziaei, L. and Eslamian, S., 2015, Recycled Water in Basin and Farm Scales, Urban Water Reuse Handbook, Ch. 65, Ed. By Eslamian, S., Taylor and Francis, CRC Group, 855-858. 
[120]Perez Sierra, J. A. and Eslamian, S., 2015, Water Reuse in Coastal Areas, Urban Water Reuse Handbook, Ch. 67, Ed. By Eslamian, S., Taylor and Francis, CRC Group, 867-874.

[121]Noor Islam, Sh., Reinstädtler, S., and Eslamian, S., 2015, Water Reuse Sustainability in Cold Climate Regions, Urban Water Reuse Handbook, Ch. 68, Ed. By Eslamian, S., Taylor and Francis, CRC Group, 875-886.

[122]Rina, K., Eslamian, S., Tyagi, G., and Singh, N., 2015, Feasibility Studies for Water Reuse Systems, Urban Water Reuse Handbook, Ch. 71, Ed. By Eslamian, S., Taylor and Francis, CRC Group, 909, 926.

[123] Salequzzaman, MD., Tariqul Islam, S. M., Shiddi quzzaman, M., and Eslamian, S., 2015. Climate Change Adaptation and Water Reuse, Urban Water Reuse Handbook, Ch. 75, Ed. By Eslamian, S., Taylor and Francis, CRC Group, 969-980.

[124]Kumar Goyal, M., Singh, V., and Eslamian, S., 2015, Impact of Climate Change on Drinking Water, Urban Water Reuse Handbook, Ch. 76, Ed. By Eslamian, S., Taylor and Francis, CRC Group, 981-1006.

[125]Hamdy, A. and Eslamian, S., 2015, Sustainable Reuse and Recycling of Treated Urban Wastewater, Urban Water Reuse Handbook, Ch. 80, Ed. By Eslamian, S., Taylor and Francis, CRC Group, 1039-1054.

[126]Thakur, J. K., Karmacharya, S., Singh, P., Gurung, D., and Eslamian, S., 2015, Water Reuse Products in Urban Areas, Urban Water Reuse Handbook, Ch. 81, Ed. By Eslamian, S., Taylor and Francis, CRC Group, 1055-1070.

[127]Eslamian, S., Sayahi, M., and Khosravi, B., 2015, Conjunctive Use of Water Reuse and Urban Water, Urban Water Reuse Handbook, Ch. 82, Ed. By Eslamian, S., Taylor and Francis, CRC Group, 1071-1078.

[128] Irfan, Z. B., and Eslamian, S., 2015, Urban Water Reuse Policy, Urban Water Reuse Handbook, Ch. 83, Ed. By Eslamian, S., Taylor and Francis, CRC Group, 1079-1096.

[129]Vafakhah, M., Eslamian, S. and Khosrobeigi Bozchaloei, S., 2014, Low-Flow Hydrology, in Handbook of Engineering Hydrology, Ch. 20, Vol. 1: Fundamentals and Applications, Ed. By Eslamian, S., Francis and Taylor, CRC Group, USA, 433-453.

[130]Cox, J. P., Shaeri Karimi, S. and Eslamian, S., 2014, Optimum Hydrometric Site Selection, in Handbook of Engineering Hydrology, Ch. 22, Vol. 1: Fundamentals and Applications, Ed. By Eslamian, S., Francis and Taylor, CRC Group, USA, 471-483.

[131]Eslamian, S. and Motevallian, S. S., 2014, Sustainability in Urban Water System, in Handbook of Engineering Hydrology, Ch. 27, Vol. 1: Fundamentals and Applications, Ed. By Eslamian, S., Francis and Taylor, CRC Group, USA, 549-562.

[132]Noor Islam, S., Karim, R., Noor Islam, A., and Eslamian, S., 2014, Wetland Hydrology, in Handbook of Engineering Hydrology, Ch. 29, Vol. 1: Fundamentals and Applications, Ed. By Eslamian, S., Francis and Taylor, CRC Group, USA, 581-605.

[133]Gargouri-Ellouze, E. and Eslamian, S. 2014, Application of Copulas in Hydrology: Geomorphological Instantaneous Unit Hydrograph and Intensity Index of Infiltration Frequency, in Handbook of Engineering Hydrology, Ch. 1, Vol. 2: Modeling, Climate Changes and Variability, Ed. By Eslamian, S., Francis and Taylor, CRC Group, USA, 1-18.

[134]Mujere, N. and Eslamian, S. 2014, Climate Change Impacts on Hydrology and Water Resources, in Handbook of Engineering Hydrology, Ch. 7, Vol. 2: Modeling, Climate Changes and Variability, Ed. By Eslamian, S., Francis and Taylor, CRC Group, USA, 113-126.

[135]Farzaneh, M. R., Eslamian, S. and Mirnezami, S. J. E. 2014, Climate Change: Uncertainty, Impact, and Adaptation, in Handbook of Engineering Hydrology, Ch. 8, Vol. 2: Modeling, Climate Changes and Variability, Ed. By Eslamian, S., Francis and Taylor, CRC Group, USA, 127-146.

[136]Goodarzi, E. and Eslamian, S. 2014, Dam Risk and Uncertainty, in Handbook of Engineering Hydrology, Ch. 9, Vol. 2: Modeling, Climate Changes and Variability, Ed. By Eslamian, S., Francis and Taylor, CRC Group, USA, 147-171.

[137]Fakhri, M., Dokohaki, H., Eslamian, S., Fazeli Farsani, I. and Farzaneh, M. R. 2014, Flow and Sediment Transport Modeling in Rivers, in Handbook of Engineering Hydrology, Ch. 13, Vol. 2: Modeling, Climate

[138] Changes and Variability, Ed. By Eslamian, S., Francis and Taylor, CRC Group, USA, 233-275.

[139]Matouq, M., Al-Bilbisi, H., El-Hasan, T. and Eslamian, S. 2014, GIS Applications in a Changing Climate, in Handbook of Engineering Hydrology, Ch. 15, Vol. 2: Modeling, Climate Changes and Variability, Ed. By Eslamian, S., Francis and Taylor, CRC Group, USA, 297-312.

[140]Noor Islam, S., Gnauck, A., Voigt, H.-J. and Eslamian, S., 2014, Hydrological Changes in Mangrove Ecosystems, in Handbook of Engineering Hydrology, Ch. 18, Vol. 2: Modeling, Climate Changes and Variability, Ed. By Eslamian, S., Francis and Taylor, CRC Group, USA, 353-373. 
[141]Kałuża, T. and Eslamian, S. 2014, Impact of the Development of Vegetation on Flow Conditions and Flood Hazards, in Handbook of Engineering Hydrology, Ch. 21, Vol. 2: Modeling, Climate Changes and Variability, Ed. By Eslamian, S., Francis and Taylor, CRC Group, USA, 415-449.

[142]Rahman, A., Haddad, Kh. and Eslamian, S., 2014, Regional Flood Frequency Analysis, 2014, in Handbook of Engineering Hydrology, Ch. 22, Vol. 2: Modeling, Climate Changes and Variability, Ed. By Eslamian, S., Francis and Taylor, CRC Group, USA, 451-469.

[143]Vafakhah, M. and Eslamian, S. 2014, Regionalization of Hydrological Variables, in Handbook of Engineering Hydrology, Ch. 23, Vol. 2: Modeling, Climate Changes and Variability, Ed. By Eslamian, S., Francis and Taylor, CRC Group, USA, 471-499.

[144]Chowdhury, R. K. and Eslamian, S. 2014, Statistical Parameters Used for Assessing Hydrological Regime, in Handbook of Engineering Hydrology, Ch. 26, Vol. 2: Modeling, Climate Changes and Variability, Ed. By Eslamian, S., Francis and Taylor, CRC Group, USA, 537-551.

[145]Mujere, N. and Eslamian, S. 2014, Impact of Urbanization on Runoff Regime, Chowdhury, R. K. and Eslamian, S. 2014, Statistical Parameters Used for Assessing Hydrological Regime, in Handbook of Engineering Hydrology, Ch. 29, Vol. 2: Modeling, Climate Changes and Variability, Ed. By Eslamian, S., Francis and Taylor, CRC Group, USA, 605-615.

[146]Gaaloul, N. and Eslamian, S., 2014, Artificial Recharge Experiences in Semiarid Areas, in Handbook of Engineering Hydrology, Ch. 2, Vol. 3: Environmental Hydrology and Water Management, Ed. By Eslamian, S., Francis and Taylor, CRC Group, USA, 17-49.

[147]Amininezhad, S. M., Amininejad, S. M., and Eslamian, S., 2014, Disinfection of Water and Nanotechnology, in Handbook of Engineering Hydrology, Ch. 3, Vol. 3: Environmental Hydrology and Water Management, Ed. By Eslamian, S., Francis and Taylor, CRC Group, USA, 51-64.

[148]Shaeri Karimi, S., Yasi, M., Cox, J. P., and Eslamian, S., 2014, Environmental Flows, in Handbook of Engineering Hydrology, Ch. 5, Vol. 3: Environmental Hydrology and Water Management, Ed. By Eslamian, S., Francis and Taylor, CRC Group, USA, 85-104.

[149]Eslamian, S., Malekian, R., and Amiri, M. J. 2014, Environmental Nanotechnology, in Handbook of Engineering Hydrology, Ch. 6, Vol. 3: Environmental Hydrology and Water Management, Ed. By Eslamian, S., Francis and Taylor, CRC Group, USA, 105-118.

[150]Deiminiat, A., and Eslamian, S., 2014, River Managed System for Flood Defense, in Handbook of Engineering Hydrology, Ch. 14, Vol. 3: Environmental Hydrology and Water Management, Ed. By Eslamian, S., Francis and Taylor, CRC Group, USA, 299-314.

[151]Deiminiat, A., Hassan Shojaee Siuki, and Eslamian, S. 2014, Tourism and River Environment, in Handbook of Engineering Hydrology, Ch. 20, Vol. 3: Environmental Hydrology and Water Management, Ed. By Eslamian, S., Francis and Taylor, CRC Group, USA, 401-419.

[152]Green, C. and Eslamian, S., 2014, Water Governance, in Handbook of Engineering Hydrology, Ch. 24, Vol. 3: Environmental Hydrology and Water Management, Ed. By Eslamian, S., Francis and Taylor, CRC Group, USA, 461-483.

[153]Eslamian, F. and Eslamian S., 2014, Water Pollution Control Using Low-Cost Natural Wastes, in Handbook of Engineering Hydrology, Ch. 25, Vol. 3: Environmental Hydrology and Water Management, Ed. By Eslamian, S., Francis and Taylor, CRC Group, USA, 485-499.

[154]He, Ch., Zhang, L., Zhang, X., and Eslamian, S., 2014, Water Security: Concept, Measurement, and Operationalization, in Handbook of Engineering Hydrology, Ch. 28, Vol. 3: Environmental Hydrology and Water Management, Ed. By Eslamian, S., Francis and Taylor, CRC Group, USA, 545-554.

[155]Fakhri, M., Farzaneh, M. R., Eslamian S. and Nazari, R., 2013, Wind speed regionalization under climate change conditions, Chapter 10, New Developments in Renewable Energy by H. Arman \& I. Yukcel, 215236.

[156]Nazari, R., Khanbilvardi, R., Hoyos, S., and Eslamian, S., 2013, Freshwater Demands and Storages, Encyclopedia of Crises Management, Sage Publication.

[157]Eslamian, S., 2012, Forecasting, Encyclopedia of Energy, Salem Press, USA, 461-464

[158]Eslamian, S., 2012, Iran, Encyclopedia of Energy, Salem Press, USA, 708-713.

[159]Eslamian, S. and Nazari, R., 2012, Nebraska, Encyclopedia of Energy, Salem Press, USA, 889-893.

[160]Nazari, R., S. Eslamian and R. Khanbilvardi, 2012, Water Reuse and Sustainability, Chapter 11, in Ecological Water Quality-Water Treatment and Reuse by K. Voudouris and D. Vousta, 241-254, Intech. 
Preparing A Land Cover Map with Emphasis on Green Space (Grass, Tree, Agriculture): by using Image Texture Filters in Panchromatic Band, Iran

[161]Eslamian, S. S., Gilroy K. L. and R. H. McCuen, 2011, Climate Change Detection and Modeling in Hydrology, Ch. 5 in "Climate Change -Research and Technology for Adaptation and Mitigation" Edited by J. Blanco and H. Kheradmand, InTech, 87-100.

Citation: Dr. Kaveh Ostad-Ali-Askari et.al. (2017) Preparing A Land Cover Map with Emphasis on Green Space (Grass, Tree, Agriculture): by using Image Texture Filters in Panchromatic Band, Iran, International Journal of Constructive Research in Civil Engineering, 3(4), pp.132-147. DOI: http://dx.doi.org/10. 20431/2454-8693.0304012

Copyright: (C) 2017 Dr. Kaveh Ostad-Ali-Askari, This is an open-access article distributed under the terms of the Creative Commons Attribution License, which permits unrestricted use, distribution, and reproduction in any medium, provided the original author and source are credited. 